\title{
Society and Manners in Early Nineteenth-Century Ulster
}

\section{Stiofán Ó Cadhla}

\section{(2) OpenEdition}

Journals

Electronic version

URL: https://journals.openedition.org/etudesirlandaises/3241

DOI: 10.4000 /etudesirlandaises.3241

ISSN: 2259-8863

\section{Publisher}

Presses universitaires de Caen

\section{Printed version}

Date of publication: 30 October 2012

Number of pages: 180-182

ISBN: 978-7535-2158-2

ISSN: 0183-973X

\section{Electronic reference}

Stiofán Ó Cadhla, "Society and Manners in Early Nineteenth-Century Ulster", Études irlandaises [Online], 37-2 | 2012, Online since 30 October 2012, connection on 29 July 2022. URL: http://

journals.openedition.org/etudesirlandaises/3241; DOI: https://doi.org/10.4000/etudesirlandaises. 3241

This text was automatically generated on 29 July 2022

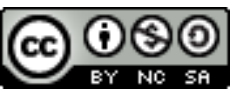

Creative Commons - Attribution-NonCommercial-ShareAlike 4.0 International - CC BY-NC-SA 4.0 https://creativecommons.org/licenses/by-nc-sa/4.0/ 


\title{
Society and Manners in Early Nineteenth-Century Ulster
}

\author{
Stiofán Ó Cadhla
}

\section{REFERENCES}

John GAMBLE and Breandán MACSUIBHINE (ed.), Society and Manners in Early NineteenthCentury Ulster, Dublin, Field Day Publications, 2011, 716 p., ISBN-13: 978-0946755431.

1 This book, all 716 pages of it, comprises of a trilogy penned in quick succession by the Presbyterian John Gamble (1770-1831), a doctor in the British army, in the early nineteenth century, in 1811, 1813 and 1819 respectively. The Gamble surname, Wolfe suggests, is Scandinavian in origin and perhaps related to the uncomplimentary moniker in Irish of gamal or foolish individual. Breandán Mac Suibhne has edited these anew with a lengthy and copiously annotated introduction, a marvellous evocative essay on life in Ulster in the nineteenth century using Gamble as a source. Travel writing, hack ethnographies or colonialist discourse on the ever fashionable subject of Ireland can be a mixed bag. The most blatantly biased can throw up interesting details at times while Gamble's, and perhaps the sheer volume of it is a testament to this, is personal, passionate and engaging. It seems to me sometimes that it is often the case that the nature of the experience amongst the people is almost irrepressible, it makes its presence felt whether that is the intention or not of the observer. It is published by Field Day in a handsomely bound hardback edition with a substantial detail of Nathaniel Grogan's 'The Itinerant Preacher' from 1783 on the cover. Grogan's work depicts an animated Wesleyan preacher standing on a barrel in a house, somewhere in Cork, gesticulating while he preaches to the assembly. The audience, however, are not at all as attentive as he might have wished them to be; many are asleep, a child plays obliviously, a woman yawns, a man picks his nose. It must say something about the apparent ambivalence of popular culture to many of the so-called metanarratives that historiography often places centre stage. Gamble's is a rambling and roving (in a good 
way) work that provides tantalising vignettes of everyday life written by what anthropologists might call "a participant observer".

2 In this amazing Ulster gazetteer Gamble first travelled through Dublin, Drogheda, Cootehill, Ballygawley, Newtownstewart and home to Strabane, each journey is very usefully illustrated by a map. The later journeys brought him to Newry, Banbridge, Belfast, Larne, Lurgan, Armagh and Coleraine. He brings you deep into the society of the day, I don't say 'deep' with any suggestion of the unfathomable indigenes but rather in terms of time, place and culture. Mac Suibhne's own essay offers a broad but detailed perspective with an illustrative selection of examples. Gamble is clearly affable and gregarious and a keen observer with an almost Proustian eye for detail. Reflecting on the the pace of the Irish coach, or is it of Irish life in general, he remarks that, "you are not obliged to devour your food like a cannibal' and 'run away like a debtor pursued by bailiffs". There is a palpable sense of the time in which the writer is writing that he succeeds in capturing, time as it is lived and experienced in everyday life, much as a writer such as John McGahern has. Gamble is not an outsider, as Mac Suibhne points out, but a returned émigré who left in the landmark year of 1798. Notwithstanding the manner in which a florid style sometimes serves to mask inherent ambivalence in travel writing and related genre this writing can be a pleasure to read, Gamble is philosophical and intelligent. In Dungiven in 1812 he takes shelter in a "cabin" from the rain to find a child rocking a cradle while the adults were outside working. It could be said that his assertion that the child "could only speak Irish" views it as an underachievement of some sort. There is, nonetheless, a singular sympathy and understanding that exceeds that of the sappers and officers of the Ordnance Survey only a few years later for example, particularly considering that Gamble was himself a physician in the British military. He is more restrained and judicial at times in his use of the quasi-racialist jargon or rhetoric. On the Irish language he writes, "This singular and most unjust contempt of the Aborigines and their language is a convincing proof (were proof wanting) how very colonial, and how little national, a large portion of the population is" (p. 362). Elsewhere he contends that "Irish is the best language in the world for a man to make love in" (p. 414). Sometimes, albeit in fine descriptions of popular behaviour, there appears to be little understanding of an ethnographic nature, rather speculation couched in benevolence. There is for example a striking account of women keening or lamenting the dead over their coffins, they "tore their hair, which they flung in handfuls on it, clasped it in their arms, beat on it with their hands, called on the deceased by his name, by a thousand tender, by a thousand almost reproachful names, to hear, to answer, to come forth" (p. 399). Perhaps falling for the ecstatic if stigmatised art of the keen or "Irish cry" Gamble finds it "sadly pleasing" and a sound "pensiveness would love to hear" (p. 400). He argues interestingly for its musicality.

There is so much in this work for anyone interested in Ireland as a whole that it is difficult to do justice to it. On "society and manners" the index is encyclopaedic from the rebellion and its suppression in 1641 to the Zodiac. From Aesop to aphrodisiacs and from flowers to wig-makers, it's all here. Mac Suibhne's footnotes, 7,000 in all, are an achievement in themselves; he set about the faithful task of tracing quotations and naming relatives or friends who were anonymous in the original texts. There are two parallel texts here in reality; the main body of text could almost be inverted to annotate the footnotes. We are left with valuable insights into the too often amorphous or supposedly unknowable audience in Grogan's painting. It must be said that Gamble, 
an intuitive and wise writer, was fortunate indeed to have such a sympathetic and learned chronicler, his work was always going to be rewarding and interesting, but Mac Suibhne has greatly enhanced it as a vital source of information, knowledge and simple entertainment pertaining to Ulster society and manners.

\section{AUTHORS}

\section{STIOFÁN Ó CADHLA}

UCC 